\title{
Equilibrium Relations between Liquid Copper, Matte and Calcium Ferrite Slag at $1523 \mathrm{~K}^{*}$
}

\author{
By Moon-Gyung Park**, Yoichi Takeda*** and Akira Yazawa***
}

\begin{abstract}
The equilibrium relations of constituent elements between matte and calcium ferrite slag have been studied. The experiments were carried out at $1523 \mathrm{~K}$ under controlled $\mathrm{SO}_{2}$ pressure or inert gas atmosphere for the three-liquid system of metallic copper-matte-slag and the two-liquid one of matte-slag.

The experimental results of the calcium ferrite slag showed considerably different equilibrium behaviours as compared with those of the silica-saturated iron silicate slag. The contents of sulfur and copper in the calcium ferrite slag increased with decreasing copper content in matte, which is closely related to the mutual dissolution between matte and slag. Therefore, it has been concluded that the calcium ferrite slag has no advantage over the iron silicate slag for the separation of slag from matte, although the present results are quite interesting from the theoretical standpoint of mutual dissolution between matte and slag.

The distribution ratios of lead with the calcium ferrite slag were about one-tenth of those with the iron silicate slag. Thus, lead is less concentrated into the calcium ferrite slag in comparison with the iron silicate slag.
\end{abstract}

\section{(Received June 5, 1984)}

Keywords: ferrite slag, matte, equilibrium study, copper smelting, continuous smelting, distribution ratio, minor element, impurity

\section{Introduction}

Calcium ferrite slag has recently been recognized as a new slag in the extractive metallurgy ${ }^{(1)(2)}$. The thermodynamic properties of the $\mathrm{FeO}-\mathrm{Fe}_{2} \mathrm{O}_{3}-\mathrm{CaO}$ system have been reported $^{(3)}$, and the equilibrium relations ${ }^{(4)}$ and the distribution equilibria of minor elements ${ }^{(5)}$ between metallic copper and calcium ferrite slag have been described in previous reports. In the usual matte smelting process, there always exists a matte phase. Thus, the equilibrium for the two- and three-liquid systems of matte-slag and copper-matte-slag is necessary to evaluate the process. An equilibrium experiment for the three-liquid system was reported by Kuxmann et al. ${ }^{(6)}$, in

* This study was originally published in Japanese in the Bulletin of the Research Institute of Mineral Dressing and Metallurgy, Tohoku University, 39 (1983), 117.

** College of Engineering, Chungbuk University, Keshin-dong, Chungju-shi, Chungcheongbuk-do, Korea.

*** The Research Institute of Mineral Dressing and Metallurgy(SENKEN), Tohoku University, Sendai 980, Japan. which the dependence of melt composition on temperature was investigated, but that on oxygen potential or matte grade was not necessarily established. Thus, the equilibrium experiments for the two- or three-liquid system were carried out at $1523 \mathrm{~K}$ under controlled $\mathrm{SO}_{2}$ pressure or inert gas atmosphere. Furthermore, a small amount of lead was added to the mixture of starting materials for the study of the distribution behaviours of lead between the condensed phases.

\section{Experimental Procedures}

Most of the experimental apparatus and techniques were similar to those described in previous papers ${ }^{(4)(7)(8)}$. The calcium ferrite slag containing $23 \% \mathrm{CaO}$ and matte were brought into equilibrium in a magnesia crucible, with and without metallic copper at $1523 \mathrm{~K}$. The slag melted in a magnesia crucible contains 1 to $2 \% \mathrm{MgO}$. The details of experimental conditions are summarized in Table 1. As shown in Table 1, the partial pressure of sulfur dioxide was controlled by $\mathrm{SO}_{2}-\mathrm{Ar}$ gas mixture. When the matte below $77 \% \mathrm{Cu}$ coexistes with metallic copper and slag, the partial pressure of $\mathrm{SO}_{2}$ is so small as not to be controlled. 
Table 1 Experimental conditions for the phase equilibria and the distribution behaviour of lead among calcium ferrite slag, matte and metallic copper at $1523 \mathrm{~K}$.

\begin{tabular}{|c|c|c|c|c|}
\hline \multirow{2}{*}{\multicolumn{2}{|c|}{$\frac{\text { System }}{\text { Atmosphere }}$}} & \multicolumn{2}{|c|}{ Copper-matte-slag } & \multirow{2}{*}{$\begin{array}{c}\text { Matte-slag } \\
10 \% \mathrm{SO}_{2}-90 \% \mathrm{Ar}\end{array}$} \\
\hline & & $\mathrm{Ar}-\mathrm{SO}_{2}{ }^{*}$ & $\mathrm{Ar}^{* *}$ & \\
\hline Matte & grade & $\sim 80 \%$ & $<77 \%$ & $40 \sim 80 \%$ \\
\hline \multirow{4}{*}{$\underset{(\mathrm{g})}{\text { Charge }}$} & slag & 4 & 12 & 4 \\
\hline & matte & 3.4 & 15 & 3.5 \\
\hline & copper & 5 & 20 & - \\
\hline & lead & $0.1-0.2$ & 1 & $0.1-0.2$ \\
\hline
\end{tabular}

* the controlled partial pressure of $\mathrm{SO}_{2}$ $\left(p_{\mathrm{SO}_{2}}=1-10^{-2}\right)$

** the measured oxygen potential $\left(p_{\mathrm{O}_{2}}<10^{-9}\right)$

Under this condition, inert Ar gas was used, and the oxygen potential was determined by using the following oxygen concentration cell:

$$
\mathrm{Pt}|\mathrm{Fe}, \mathrm{FeO}| \mathrm{ZrO}_{2} \cdot \mathrm{MgO}|\mathrm{Cu}(1)| \mathrm{W} \mid \mathrm{Pt} \text {. }
$$

By using the standard free energy data for the oxidation of solid iron to solid ferrous oxide ${ }^{(9)}$, the relationship between the oxygen partial pressure, $p_{\mathrm{O}_{2}}$, and the electromotive force, $E / \mathrm{mV}$, was derived as follows:

$$
\log p_{\mathrm{O}_{2}}=\log \left(P_{\mathrm{O}_{2}} / P^{Q}\right)=\frac{E / \mathrm{mV}-859.4}{75.54},
$$

where $P_{\mathrm{O}_{2}}$ is the oxygen pressure of equilibrium and $P^{Q}$ is the standard pressure, $101325 \mathrm{~Pa}$.

For the attainment of equilibrium a holding time $2.2 \times 10^{4} \mathrm{~s}$ was considered to be enough for the system under inert gas where the equilibrium was established between liquid phases without participation of gaseous species. On the other hand, the samples were kept for $1.1 \times 10^{5} \mathrm{~s}$ for the $\mathrm{SO}_{2}-\mathrm{Ar}$ gas experiment with respect to the confirmation of the previous reports ${ }^{(4)(7)(8)}$.

The samples were analyzed by the following methods. The large content of copper or calcium in matte and slag was determined by EDTA spectrophotometric titration and that of iron by oxidation-reduction titration with ascorbic $\operatorname{acid}^{(9)}$. The small content of copper, calcium, iron or lead in the corresponding phase was determined by atomic absorption spectrophotometry. The sulfur content in matte and slag was analyzed by the gravimetric method of barium sulfate precipitate.

The distribution ratios of lead were defined by the following equations:

$$
\begin{gathered}
L_{\mathrm{Pb}}^{\mathrm{s} / \mathrm{m}}=\frac{\% \mathrm{~Pb} \text { in slag }}{\% \mathrm{~Pb} \text { in matte }}, \\
L_{\mathrm{Pb}}^{\mathrm{s} / \mathrm{c}}=\frac{\% \mathrm{~Pb} \text { in slag }}{\% \mathrm{~Pb} \text { in metallic copper }}
\end{gathered}
$$

and

$$
L_{\mathrm{Pb}}^{\mathrm{m} / \mathrm{c}}=\frac{\% \mathrm{~Pb} \text { in matte }}{\% \mathrm{~Pb} \text { in metallic copper }}
$$

\section{Results and Discussion}

\section{Sulfur contents in slag}

Sulfur is one constituent element of matte so that the sulfur content in slag is considered to be closely correlated to the mutual dissolution between matte and slag. In Fig. 1, the sulfur contents in slag equilibrating with matte, with and without metallic copper are plotted against the copper content in matte. In the figure, the squares show the results under matte-slag equilibrium, and the circles show those under metallic copper-matte-slag equilibrium, of which the open circles are for the $\mathrm{SO}_{2}-\mathrm{Ar}$ gas

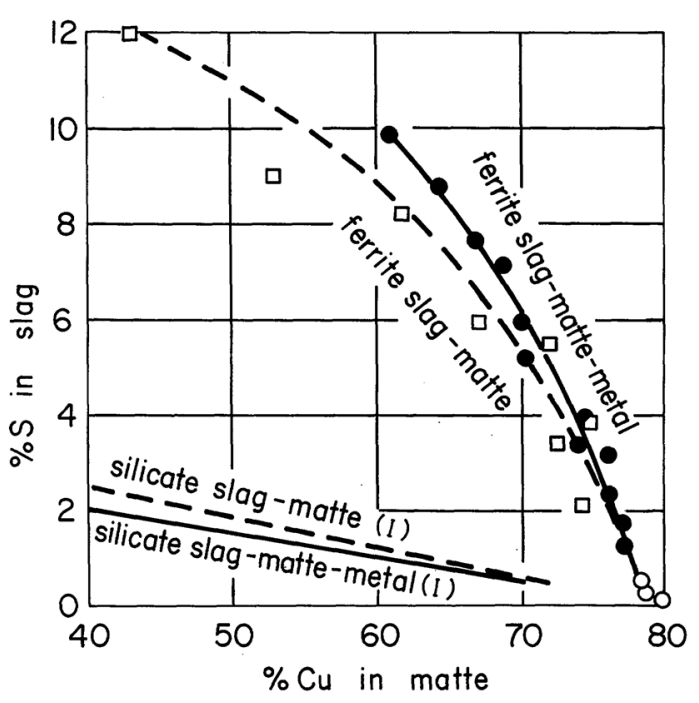

Fig. 1 Sulfur content in slag as a function of copper content in matte $\left(\mathrm{O}, \square: \mathrm{SO}_{2}-\mathrm{Ar}\right.$ gas, $\mathrm{O}$ : Ar gas. (I): Yazawa et $\left.a l .^{(10)}\right)$. 
mixture and the closed ones for the inert gas. The results for the iron silicate slag obtained by Yazawa et al. ${ }^{(10)}$ are also shown in Fig. 1.

The solubility of sulfur in the calcium ferrite salg is very small around a matte grade of 80 $\%$, but, with decreasing matte grade, it increases much more sharply than that in the iron silicate slag. This high content of sulfur in slag is considered to be mainly caused by the dissolution of iron sulphide, since with decreasing matte grade the amount of iron sulphide in matte is increasing and the mutual dissolution between matte and slag increases. As the mutual dissolution increases, the phase separation between matte and slag becomes difficult. In fact, for matte-slag equilibrium, the matte and ferrite slag become one homogeneous melt, when the matte grade is lower than $40 \%$. For the metallic copper-matte-slag system, a similar result was observed at a matte grade of $50 \%$, i.e. there were only two phases of metallic copper and the slag containing about $14 \%$ of sulfur. Therefore, it will be said that $\mathrm{CaO}$ does not play a better role than $\mathrm{SiO}_{2}$ for the separation of slag from matte. This may be ascribable to the facts that typical ionic melt is formed between silica and iron oxide, while $\mathrm{CaO}$ is not a network former and the basic character of the ferrite slag does not differ so much from that of the matte phase. The problem on the mutual dissolution between matte and iron silicate slag was already clarified by one of the authors ${ }^{(11)}$, but there needs a more fundamental study concerning the mutual dissolution between matte and calcium ferrite slag.

\section{Copper contents in slag}

The copper content in slag is closely related to the sulfur content in slag in view of the phase equilibrium between matte and slag. The copper contents in slag are plotted in Fig. 2 using the same descriptions as in Fig. 1. In this figure the copper content in slag shows a minimum value around a matte grade of $78 \%$ and increases sharply with decreasing matte grade from $78 \%$. This tendency is basically similar to that of the iron silicate $\operatorname{slag}^{(10)}$, as shown together in Fig. 2, but is much radical due to the substantial mutual dissolution bet-

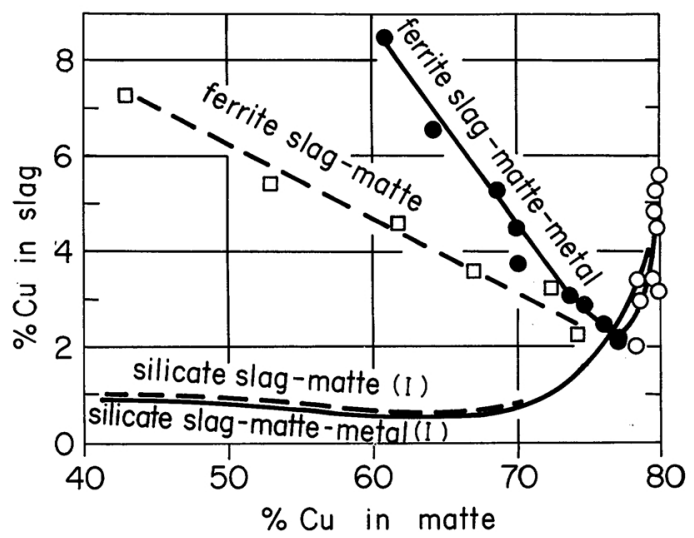

Fig. 2 Copper content in slag as a function of copper content in matte $\left(\mathrm{O}, \square\right.$ : $\mathrm{SO}_{2}-\mathrm{Ar}$ gas, $\mathrm{O}$ : Ar gas, (I): Yazawa et $\left.a{ }^{(10)}\right)$.

ween matte and calcium ferrite slag.

The differences in the copper contents between the two kinds of slag are more clearly replotted against the oxygen partial pressure, the sulfur dioxide partial pressure or the matte grade in Fig. 3. The relationship between the oxygen partial pressure and the sulfur dioxide partial pressure is calculated as follows according to the same procedure as in a previous report $^{(12)}$ :

$$
\log p_{\mathrm{O}_{2}}=\log p_{\mathrm{SO}_{2}}-5.60 \text {. }
$$

Above the matte grade of $78 \%$ the oxygen partial pressure is becoming high and copper solubilities approach the value of metallic cop-

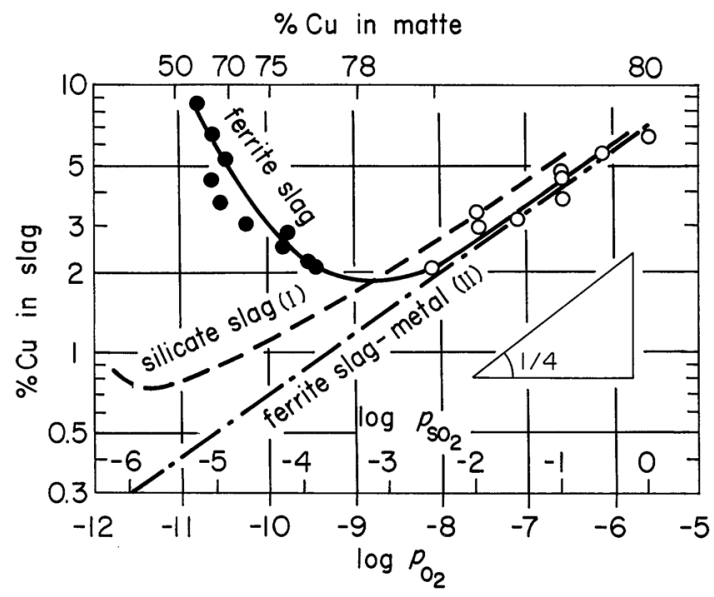

Fig. 3 Effect of oxygen potential on copper content in slag $\left(\mathrm{O}: \mathrm{SO}_{2}-\mathrm{Ar}\right.$ gas, $\mathrm{O}$ : Ar gas, $(\mathrm{I})^{(10)}(\mathrm{II})^{(4)}$ : Yazawa et al.). 
per-slag equilibrium ${ }^{(4)}$. The solubilities are proportional to the oxygen partial pressure, from which the copper in slag is considered to exist mainly as an oxidic species. With decreasing oxygen potential, on the other hand, the copper solubilities increase again, which is considered to have a close relationship to the increase of the sulfur contents in slag, as described in the previous section. In the range of low oxygen partial pressure, the amount of iron sulphide dissolved in the ferrite slag is considerable, and the copper in slag is considered to exist mainly as a sulphidic species.

\section{Calcium contents in matte}

Calcium is one constituent element of slag so that calcium content in matte is also considered to be closely correlated to the mutual dissolution between matte and slag. The calcium contents in matte for matte-slag and metallic copper-matte-slag equilibrium are plotted against the copper content in matte in Fig. 4. In this figure the calcium contents in matte increase gradually with decreasing matte grade for both conditions of two- and three-liquid phase equilibria, which also reflects the behaviour of mutual dissolution between matte and slag.

\section{Distribution equilibrium of lead}

The distribution equilibrium of lead between the condensed phases is considered to be essential, in order to understand the available discard or recovery routes. The distribution ratios between slag and metallic copper under the coexistence of matte are plotted in Fig. 5 using the same descriptions as in Fig. 1 and Fig.

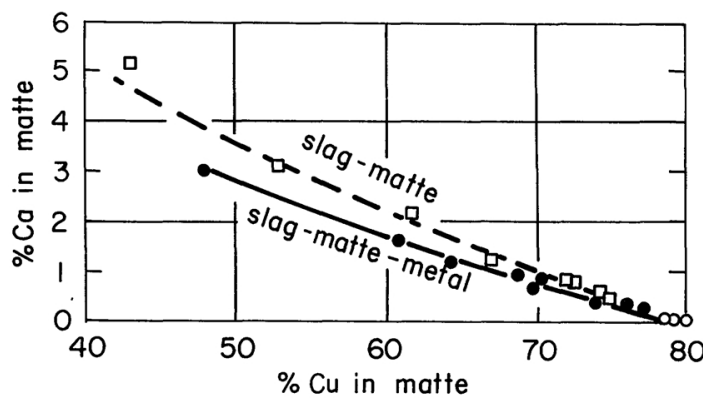

Fig. 4 Calcium content in matte as a function of copper content in matte ( $\bigcirc, \square$ : $\mathrm{SO}_{2}-\mathrm{Ar}$ gas, $\mathrm{O}$ : Ar gas).

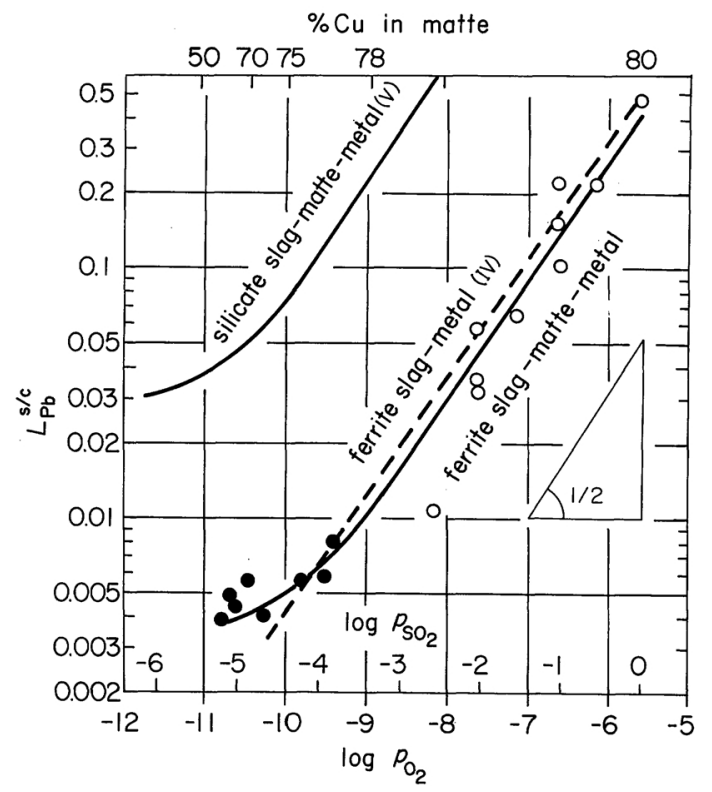

Fig. 5 Effect of oxygen potential on the distribution ratios of lead between slag and metallic copper $\left(\mathrm{O}: \mathrm{SO}_{2}-\right.$ Ar gas, O: Ar gas, (IV): Takeda et al.,$^{(5)}(\mathrm{V})$ : Kaiura et $\left.a l .{ }^{(8)}\right)$.

3. According to these results, the distribution ratios of lead between the calcium ferrite slag and metallic copper are about one-tenth of those between the iron silicate slag and metallic copper. Thus, lead is less concentrated into the calcium ferrite slag than into the iron silicate slag. In the ranges of high oxygen potential, the distribution ratios of lead between slag and copper in the metallic copper-matte-slag system show nearly the same values with those in the plain copper-slag system ${ }^{(5)}$, and are proportional to $\log p_{\mathrm{O}_{2}}$. This means that the coexistence of matte hardly affects the distribution ratios of lead'. Moreover, judging from the slope of the lines, $\mathrm{PbO}$ can be reasonably assumed as a predominant form of lead in slag.

The distribution ratios of lead between slag and matte for the equilibrium conditions of matte-slag and copper-matte-slag are illustrated against the matte grade in Fig. 6. According to these results, the distribution ratios of lead for the matte-slag equilibrium are larger than those under coexistence of the metal phase. This is ascribed to the difference in the oxygen potential between the two 


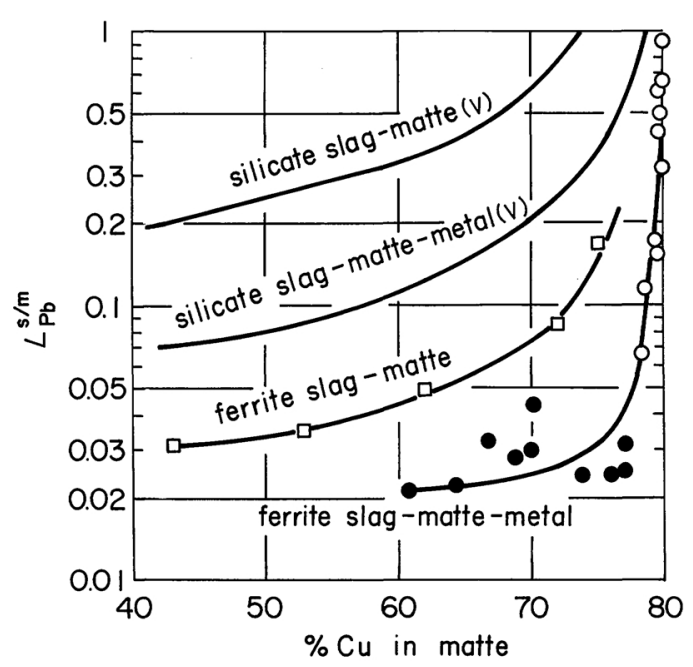

Fig. 6 Distribution ratios of lead between slag and matte as a function of copper content in matte $\left(\mathrm{O}, \square: \mathrm{SO}_{2}-\mathrm{Ar}\right.$ gas, $\mathrm{O}$ : Ar gas, (V): Kaiura et al. ${ }^{(8)}$ ).

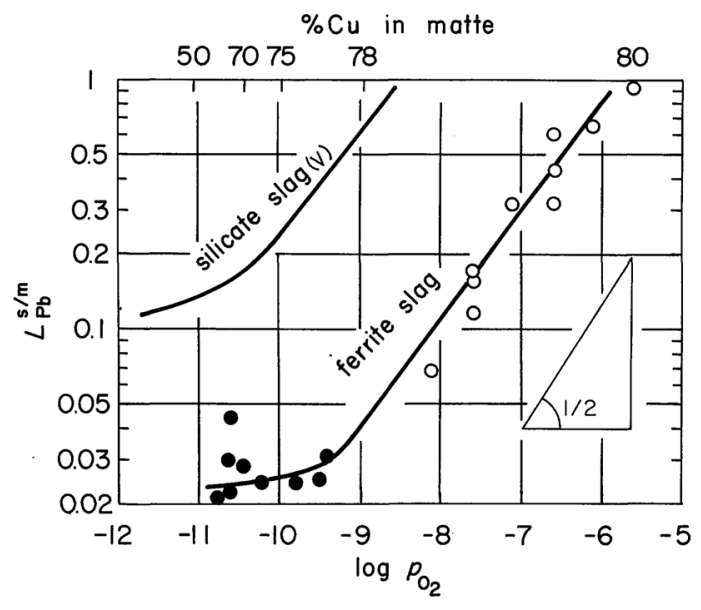

Fig. 7 Effect of oxygen potential on the distribution ratios of lead between slag and matte $\left(\mathrm{O}: \mathrm{SO}_{2}-\mathrm{Ar}\right.$ gas, : Ar gas, (V): Kaiura et al. ${ }^{(8)}$ ).

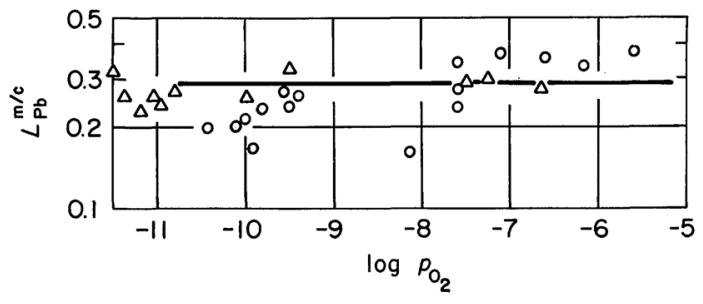

Fig. 8 Distribution ratios of lead between matte and metallic copper $(O$ : ferrite slag-matte-metal system, $\triangle$ : silicate slag-matte-metal system according to Kashima et al. $\left.{ }^{(13)}\right)$. equilibrium conditions, i.e. at the same matte grade the oxygen potential of the matte-slag equilibrium is much larger than that of the copper-matte-slag equilibrium, as well understood from the sulfur-oxygen potential diagram ${ }^{(8)}$. Thus the predominant dissolved form of lead in slag can be estimated to be an oxidic species. Figure 6 also shows that lead is less concentrated into the calcium ferrite slag than into the iron silicate slag.

In the composition ranges of white metal, the differences in $L_{\mathrm{Pb}}^{\mathrm{s} / \mathrm{m}}$ between the two kinds of slag are more clearly plotted in Fig. 7. Once again the values with the calcium ferrite slag are about one-tenth of those with the iron silicate slag. The distribution ratios of lead between matte and metallic copper, $L_{\mathrm{Pb}}^{\mathrm{m}} / \mathrm{c}$ are 0.2 to 0.4, as shown in Fig. 8, and agree with the reported values ${ }^{(13)}$.

\section{Summary}

The heterogeneous equilibrium relations and the distribution behaviours of lead among metallic copper, matte and calcium ferrite slag have been investigated at $1523 \mathrm{~K}$ under controlled $\mathrm{SO}_{2}$ pressure or inert gas atmosphere. The results are as follows:

(1) The sulfur content in the calcium ferrite slag is very small around a matte grade of $80 \%$, but as the matte grade decreases, it increases much more sharply than that in the iron silicate slag.

(2) The copper content in the calcium ferrite slag shows a minimum value around a matte grade of $78 \%$, and it also increases much more sharply with decreasing matte grade from $78 \%$.

(3) The calcium content in matte increases gradually with decreasing matte grade.

(4) The above results altogether show that matte and calcium ferrite slag dissolve each other more easily than matte and iron silicate slag. Therefore, it can be said that $\mathrm{CaO}$ does not play a better role than $\mathrm{SiO}_{2}$ for the separation of slag from matte, and the practical use of the ferrite slag in matte smelting stage is not interesting except for the special case.

(5) The distribution ratios of lead with the calcium ferrite slag are about one-tenth of 
those with the iron silicate slag. Thus, lead is less concentrated into the calcium ferrite slag than into the iron silicate slag, and lead is reasonably concluded to exist as $\mathrm{PbO}$ in the slags.

\section{Acknowledgement}

The present investigation was supported partly by the Grant-in-Aid for Scientific Research from Ministry of Education, Science and Culture, Japan.

\section{REFERENCES}

(1) T. Nagano and T. Suzuki: Extractive Metallurgy of Copper, vol. 1, Ed. by J. C. Yannopoulos and J. C. Agarwal, AIME, (1976), p. 439.

(2) A. Yazawa: Erzmetall, 30 (1977), 511.

(3) Y. Takeda, S. Nakazawa and A. Yazawa: Can. Met.
Quart., 19 (1980), 297.

(4) A. Yazawa and Y. Takeda: Trans. Japan Inst. Metals, 23 (1982), 328.

(5) Y. Takeda, S. Ishiwata and A. Yazawa: Trans. Japan Inst. Metals, 24 (1983), 518.

(6) U. Kuxmann and H. Bussmann: Erzmetall, 27 (1974), 353.

(7) M. Eguchi and A. Yazawa: Trans. Japan Inst. Metals, 18 (1977), 353.

(8) G. H. Kaiura, K. Watanabe and A. Yazawa: Can. Met. Quart., 19 (1980), 191.

(9) K. Mikami: Denki Kagaku, 27 (1978), 160.

(10) A. Yazawa, M. Oida and U. Nishikawa: J. Min. Metall. Inst. Japan, 98 (1982), 963.

(11) A. Yazawa: Technology Reports of Tohoku University, 21 (1956), 31.

(12) M. Eguchi, H. Sawaguchi and A. Yazawa: J. Min. Metall. Inst. Japan, 93 (1977), 33.

(13) M. Kashima, U. Nishikawa, M. Eguchi and A. Yazawa: J. Min. Metall. Inst. Japan, 96 (1980), 907. 